\title{
Influence of different temperature regimes at torrefaction of chicken litter on yield and properties of products
}

\author{
Olga Larina ${ }^{1}$, and Yana Pudova ${ }^{1 *}$ \\ ${ }^{1}$ Joint Institute for High Temperatures of the Russian Academy of Sciences, Izhorskaya st. 13 Bd.2,Moscow, Russia
}

\begin{abstract}
The purpose of the research is study the influence of the torrefaction process on the fuel properties of the chicken litter. Experimental studies on lab-scale system at five temperature regimes of torrefaction $\left(220,240,260,280\right.$, and $\left.300{ }^{\circ} \mathrm{C}\right)$ with a holding time determined using thermogravimetric analysis were conducted. The products of the torrefaction are solid residue, non-condensable gases, and tar. For the feedstock and torrefied material the elemental composition, the lower calorific value, hygroscopicity limit and bulk density are determined. For liquid fraction the analysis of the chemical composition is carried out. The properties of non-condensable gases as chemical composition and calorific value - are investigated. Mass yields of the solid residue and tar, and specific volume yield of the non-condensable gases are presented. The conclusion about the optimum temperature regime for torrefaction of chicken litter based on the results of experimental studies is made.
\end{abstract}

\section{Introduction}

In connection with the growing urgency of solving anthropogenic environmental problems at the 21st session of the Conference of the Parties to the UN Framework Convention on Climate Change, an agreement on combating climate change and starting the activities necessary to reduce greenhouse gas emissions was concluded. This agreement was signed, including by Russia, as a result of which in the near future the renewable energy market will gain momentum [1]. A promising direction of development is the energy utilization of various types of biomass, which is currently becoming one of the largest participants in sustainable energy production. It accounts for about $10 \%$ of total world energy production [2].

The main part of the processed biomass is wood. However, the biomass also includes bio-waste as chicken litter formed in poultry farms. The chicken litter is both a valuable resource and an unavoidable by-product that must be disposed of due to the deterioration of the ecological situation near the poultry farms. A common method of utilization of the chicken litter is considered to be use as a fertilizer in agriculture due to the high content of nitrogen, phosphorus, and potassium [3]. However, due to the lack of a sufficient amount of land for need of fertilizer, expensive transportation of waste to storage sites, and environmental pollution, it is necessary to investigate the possibility of alternative use of this. For example, use as a solid fuel.

According to the research, the results of which are presented in [4], in the chicken litter contains a significant energy potential. The calorific value to a dry mass of this material is $16 \mathrm{MJ} / \mathrm{kg}$, which is comparable with the calorific value of wood [5]. However, chicken litter has a moisture content of about 30\% [6] and high bacterial contamination due to the content of pathogenic microflora. In this connection, the storage of this raw material before burning, as well as the burning itself, becomes problematic.

Thermochemical conversion of biomass is one of the ways to solve such problems. The less energy consuming compared to other thermal processing methods and readily available from the point of view of equipment and conditions method of thermochemical conversion is torrefaction [2]. Torrefaction is a type of pyrolysis at low temperatures $\left(200-300^{\circ} \mathrm{C}\right)$ and heating rates less than $50^{\circ} \mathrm{C} / \mathrm{min}$ [2], [7]. Torrefaction is aimed at changing the thermal characteristics of biomass in the direction of biochar.

According to the data presented in [1], torrefaction in relation to plant biomass (primary biomass) improves hydrophobic properties and increases the calorific value. This article presents the results of an experimental study on the effect of torrefaction on characteristics of chicken litter and other products of process.

\section{Initial raw material}

The chicken litter, consisting on chicken manure and sawdust, pressed into pellets was used as the initial raw material for researches. The results of the elemental analysis of the feedstock are presented in Fig. 1.

pudova.y.d@mail.ru 


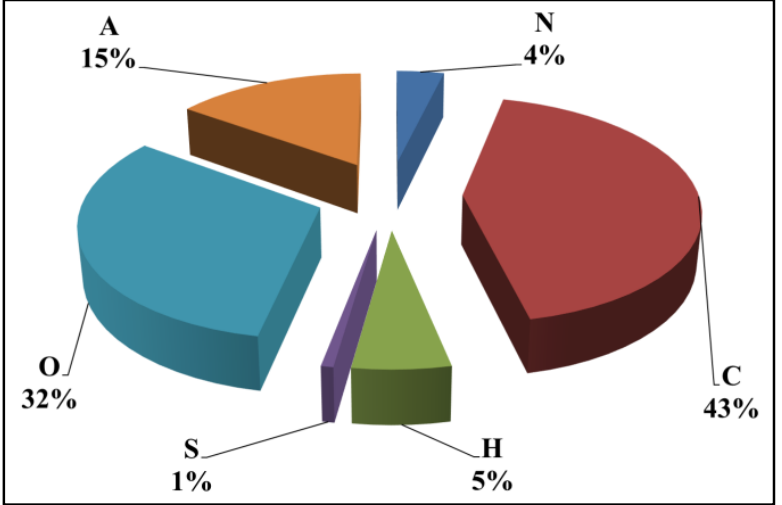

Fig. 1. The elemental composition of initial raw material (on dry basis).

The largest part of the mass of the feedstock is carbon. Its share in chicken litter is comparable to the carbon content in wood. For softwood this value is $50.5 \%$ and for hardwood is $49.6 \%$ [5]. The second of mass element is oxygen. The ash content is $15 \%$. High ash content is characteristic of secondary biomass, for pure chicken manure this value is about $34 \%$ [8]. Since the ash content of sawdust is less than $1 \%$ [9], it can be concluded that the proportion of chicken manure in the composition of initial raw material is less than $50 \%$. Secondary biomass contains sulfur, unlike wood, although sulfur accounts for less than $1 \%$.

The main fuel characteristics of the initial raw material as the lower calorific value, showing the energy potential of the raw material, bulk density, which necessary for transportation and storage of material, and the hygroscopicity limit, which characterizes the ability of the material to absorb moisture from the environment presented in Table 1 .

Table 1. The fuel characteristics of chicken litter.

\begin{tabular}{|c|c|c|}
\hline $\begin{array}{c}\text { Lower calorific } \\
\text { value }, \mathrm{MJ} / \mathrm{kg}\end{array}$ & $\begin{array}{c}\text { Bulk density, } \\
\mathrm{kg} / \mathrm{m}^{3}\end{array}$ & $\begin{array}{c}\text { Hygroscopicity } \\
\text { limit, } \%\end{array}$ \\
\hline 17.03 & 597.0 & 21 \\
\hline
\end{tabular}

High carbon content leads to the lower calorific value of more than $17 \mathrm{MJ} / \mathrm{kg}$, which is also comparable with the same value for wood. For softwood this value is 18.8 $\mathrm{MJ} / \mathrm{kg}$, for hardwood is $18.4 \mathrm{MJ} / \mathrm{kg}$ [5].

\section{Experimental procedure}

Experimental researches on the torrefaction of biomass were carried out on a lab-scale system consisting of laboratory setup and measurement equipment. The laboratory setup consists of a torrefaction reactor, the volume of which is 0.361 , a heated gas pipe and a condenser, which is a vertically installed heat exchanger of the Fild Tube type with external flow-through cooling. The scheme of the laboratory setup is presented in [10]. The initial raw material is placed in the torrefaction reactor after preliminary thermal drying to a relative moisture content of $1 \%$. The backfill weight in experiments with chicken litter was 200 g. Experimental researches were carried out at five temperature regimes of torrefaction $\left(220,240,260,280\right.$, and $\left.300{ }^{\circ} \mathrm{C}\right)$ with a holding time determined using thermogravimetric analysis. The holding time for all five temperature regimes was 40 minutes. The necessary condition of torrefaction is the creation of an oxygen-free environment, therefore, after filling-up of the lab-scale system a leak test and purging with argon were carried out. In the condenser volatile matters are divided into liquid and non-condensable gases. During the experiment, the torrefaction liquid settles on the walls and flows to the bottom of the condenser, to which the test tube was connected. The mass of the liquid was measured by weighing the condenser with the test tube before and after the experiment. Non-condensable gases entered to the gas meter to measure the volume and then to a flow-through gas analyzer to determine the chemical composition.

Thus, the products of the torrefaction process are solid residue, non-condensable gases and torrefaction liquid.

\section{Characteristics of products of the torrefaction}

\subsection{Solid residue}

The initial raw material coincides with the solid residue by the state of matter, therefore, it becomes possible to estimate the change of its characteristics during torrefaction. The mass yield of solid residue depending on the process temperature is presented in Fig. 2.

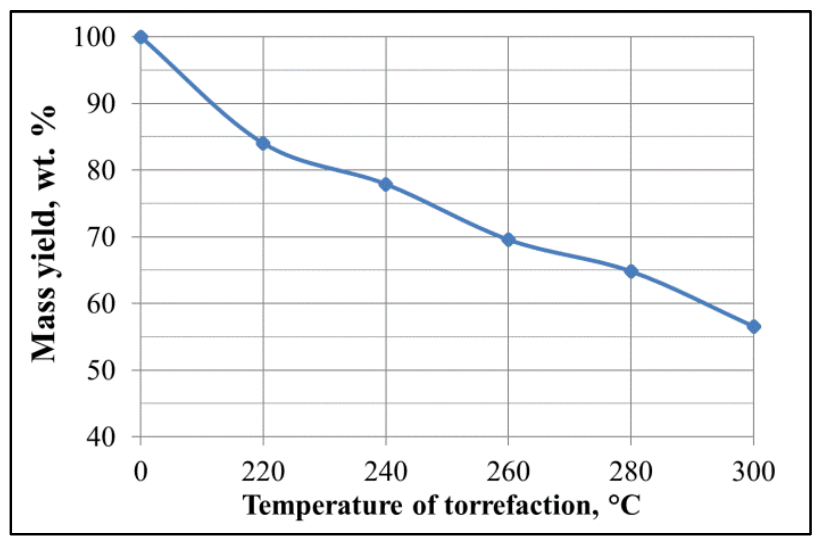

Fig. 2. Mass yield of solid product at torrefaction of chicken litter.

At a torrefaction temperature of $220^{\circ} \mathrm{C}$, the mass loss of the feedstock of $16 \%$ is observed. The maximum mass loss is $43.5 \%$ at $300{ }^{\circ} \mathrm{C}$. Accordingly, the decrease of feedstock mass during heat treatment rises by more than 2.5 times in the range from 220 to $300{ }^{\circ} \mathrm{C}$.

The change of the elemental composition of the solid residue depending on the temperature regime of torrefaction is presented in Table 2 .

Table 2. The elemental composition of the materials (on dry basis), \%. 


\begin{tabular}{|c|c|c|c|c|c|c|}
\hline \multirow{2}{*}{ Element } & \multirow{2}{*}{$\begin{array}{c}\text { Raw } \\
\text { material }\end{array}$} & \multicolumn{5}{|c|}{ Temperature of torrefaction, ${ }^{\circ} \mathrm{C}$} \\
\cline { 3 - 7 } & 220 & 240 & 260 & 280 & 300 \\
\hline $\mathrm{C}$ & 42.86 & 49.06 & 49.75 & 51.52 & 54.28 & 53.30 \\
\hline $\mathrm{H}$ & 5.70 & 5.73 & 5.39 & 5.26 & 5.03 & 4.63 \\
\hline $\mathrm{N}$ & 3.76 & 4.25 & 4.42 & 4.49 & 4.95 & 5.35 \\
\hline $\mathrm{S}$ & 0.72 & 0.73 & 0.87 & 0.92 & 0.93 & 1.02 \\
\hline $\mathrm{O}$ & 31.89 & 24.51 & 22.52 & 19.06 & 14.29 & 11.60 \\
\hline$A$ & 15.07 & 15.72 & 17.05 & 18.76 & 20.52 & 24.10 \\
\hline Total: & 100 & 100 & 100 & 100 & 100 & 100 \\
\hline
\end{tabular}

Torrefaction has the greatest effect on the content of carbon, oxygen, and ash in the composition of the solid residue. At the extreme limit of the torrefaction temperature of $220{ }^{\circ} \mathrm{C}$, there is a sharp drop of oxygen by $7.4 \%$ and a strong growth of carbon content by $6.2 \%$ compared with the initial raw material. With an increase of the torrefaction temperature, the oxygen content continues to fall and at $300{ }^{\circ} \mathrm{C}$ this value decreases 2.1 times as compared with torrefaction at $220{ }^{\circ} \mathrm{C}$ and almost 3 times as compared with the initial raw material. The torrefaction process promotes carbon growth in the material. Carbon come out along with volatile components, but the rate of fall in the mass of raw materials under the influence of temperature is higher than the rate of release of carbon. The increase of carbon content occurs up to $280{ }^{\circ} \mathrm{C}$, at which this value reaches a value of $54.3 \%$. The material torrefied at $300{ }^{\circ} \mathrm{C}$ already has the lower carbon content. At the same time, the curve characterizing the growth of ash content increases in proportion to the mass loss. The ash content of torrefied at $300{ }^{\circ} \mathrm{C}$ chicken litter compared with the initial raw material increases by 1.5 times. The total share of hydrogen, nitrogen, and sulfur in the initial raw material and in solid residue of all temperature regimes of torrefaction is no more than $11 \%$. It can be seen that the sulfur content remains virtually unchanged. The proportions of hydrogen and nitrogen change insignificantly with the growth of heat treatment temperature (no more than $1.6 \%$ ).

The change of the main fuel properties of the solid residue depending on the torrefaction temperature is shown in Fig. 3

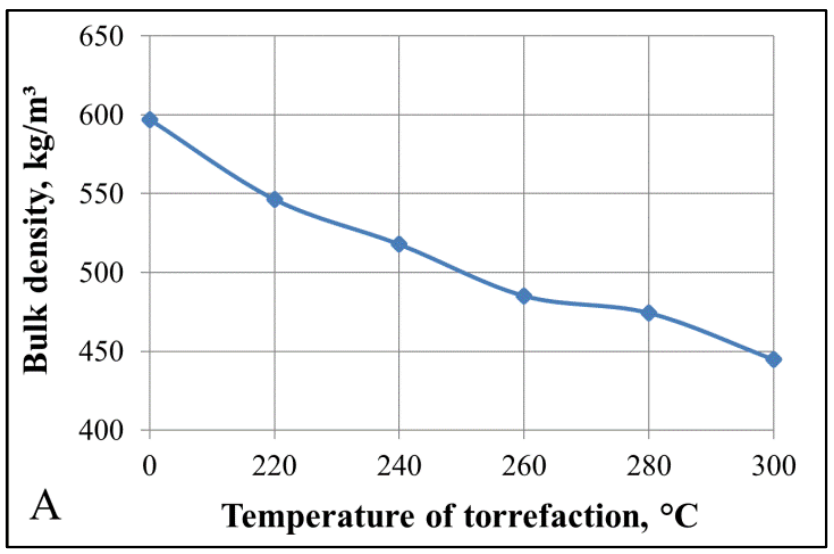

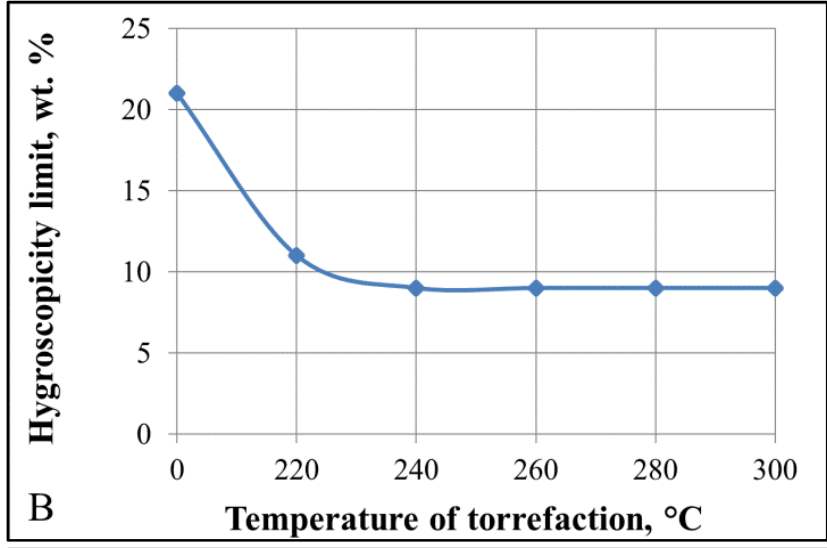

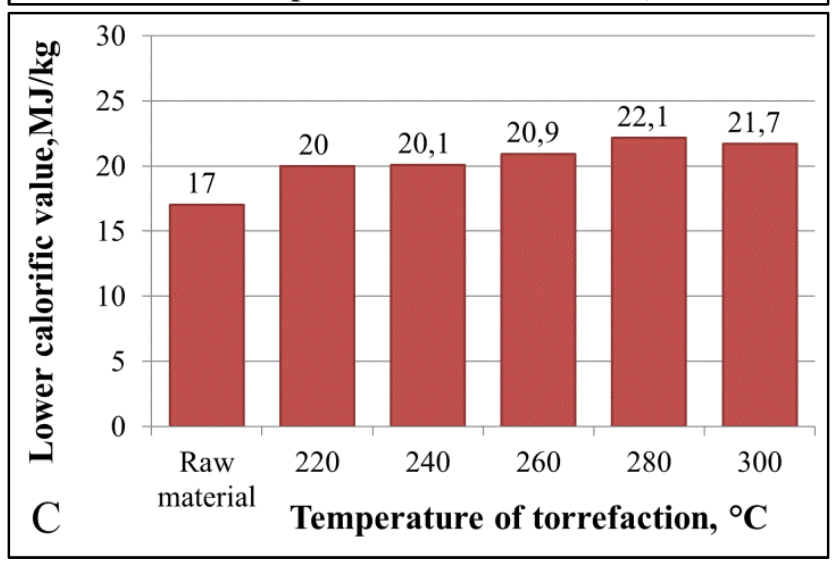

Fig. 3. Depending the fuel properties of the chicken litter on the torrefaction temperature.

Bulk density, measured in accordance with [11], is an important indicator at transporting biofuel. It allows to estimate specific energy consumption. Information on bulk density makes it possible to calculate the required capacity of vehicles for transportation of fuel and premises for its storage. The tendency of decrease of bulk density shown in Fig. 3A directly depends on the reduction of the solid residue mass yield. With growth of the torrefaction temperature, a decrease of the bulk density is observed. This value became by $25 \%$ less at of $300{ }^{\circ} \mathrm{C}$ compared to the initial raw material.

The hygroscopicity limit, measured in accordance with [12], shows how much moisture the material is able to absorb from the environment. For bio-waste this indicator plays an important role, since the material contains pathogenic microflora, which develops in a humid environment. However, torrefaction, together with a decrease in the hygroscopicity limit, also reduces the sanitary contamination of the material. As shown in fig. 3B, the hygroscopicity limit decreases from $21 \%$ for initial raw material to $9 \%$ for solid residue at $240{ }^{\circ} \mathrm{C}$ and then remains constant. The increased moisture in the air is detrimental to the raw material, since it leads to the destruction of its form (pellets). Torrefaction allows you to simplify the storage conditions of pellets. At the limit of hygroscopicity of $9 \%$ the pellets can be stored in the open air even in rainy weather.

An important thermotechnical characteristic of a fuel is the lower calorific value, which indicates the amount of heat released at complete combustion of a substance. The diagram of change in the lower calorific value of the 
chicken litter, calculated using the empirical Mendeleev's formula [13], is shown in Fig. 3C. As well as for the carbon content, the lower calorific value increases and reaches a maximum at a temperature of $280{ }^{\circ} \mathrm{C}$.

\subsection{Torrefaction liquid}

The second product of torrefaction is a torrefaction liquid. The changing mass yield of the liquid product during the torrefaction of chicken litter is shown in Fig.4.

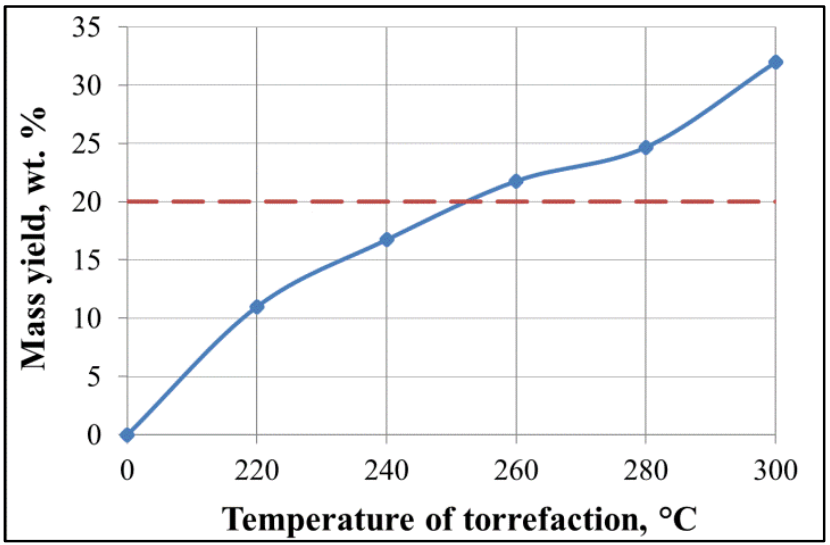

Fig. 4. Mass yield of liquid product at chicken litter torrefaction.

At a torrefaction temperature of $220{ }^{\circ} \mathrm{C}$, the mass yield of the liquid is $11 \%$ and it increases with growth of process temperature. At $300{ }^{\circ} \mathrm{C}$, the mass yield is already $32 \%$, which is almost 3 times higher than one at $220{ }^{\circ} \mathrm{C}$. It can be seen from the figure that the greatest intensity of the liquid yield occurs when the torrefaction temperature exceeds $280{ }^{\circ} \mathrm{C}$. This may be due to an increase of the intensity of the of heavy hydrocarbon compound yield.

The chemical analysis of liquid fraction samples the mass yield of which was more than $20 \%$ (red dotted line in Fig. 4) was made. The result of the analysis and the lower calorific value calculated on its basis are presented in Table 3.

Table 3. The fuel characteristics of chicken litter.

\begin{tabular}{|c|c|c|c|}
\hline & \multicolumn{3}{|c|}{ Temperature of torrefaction, ${ }^{\circ} \mathrm{C}$} \\
\hline & 260 & 280 & 300 \\
\hline \multicolumn{4}{|l|}{ Composition, wt. \% } \\
\hline $\mathrm{H}_{2} \mathrm{O}$ & 75.8 & 82.2 & 79.1 \\
\hline $\mathrm{C}_{\mathrm{n}} \mathrm{H}_{\mathrm{m}} \mathrm{O}_{\mathrm{k}}$ & 22.1 & 17.6 & 20.9 \\
\hline $\mathrm{C}_{\mathrm{n}} \mathrm{H}_{\mathrm{m}} \mathrm{N}_{\mathrm{j}}, \mathrm{C}_{\mathrm{n}} \mathrm{H}_{\mathrm{m}} \mathrm{N}_{\mathrm{j}} \mathrm{O}_{\mathrm{k}}$ & 2.1 & 0.2 & 0 \\
\hline Total & 100 & 100 & 100 \\
\hline \multicolumn{4}{|c|}{ Lower calorific value, $\mathrm{MJ} / \mathrm{kg}$} \\
\hline Torrefaction liquid & 7.5 & 6.4 & 8.5 \\
\hline $\begin{array}{c}\text { Organic part } \\
\left(\mathrm{C}_{\mathrm{n}} \mathrm{H}_{\mathrm{m}} \mathrm{N}_{\mathrm{j}} \mathrm{O}_{\mathrm{k}}+\right. \\
\left.\mathrm{C}_{\mathrm{n}} \mathrm{H}_{\mathrm{m}} \mathrm{N}_{\mathrm{j}}+\mathrm{C}_{\mathrm{n}} \mathrm{H}_{\mathrm{m}} \mathrm{N}_{\mathrm{j}} \mathrm{O}_{\mathrm{k}}\right)\end{array}$ & 25.2 & 27.4 & 35.7 \\
\hline
\end{tabular}

The most part of the torrefaction liquid is water (from
75 to $82 \mathrm{wt} . \%$ ). The organic part consists of tar in the form of $\mathrm{CnHmOk}$ and nitrogen-containing compounds in the form of $\mathrm{CnHmNjOk}$ and $\mathrm{CnHmNj}$. The water in the composition of the liquid fraction consists of moisture obtained from the feedstock, as well as pyrogenic water resulting from the decomposition of the polymer chains from the torrefaction tar. It can be seen that the content of nitrogen-containing compounds decreases with increasing temperature of torrefaction. At $300{ }^{\circ} \mathrm{C}$, it is completely absent in the composition of the torrefaction liquid.

The results of the calculation of the calorific value of the torrefaction fluid and its separate organic part showed that moisture significantly affects its thermotechnical properties. The water in the composition causes the separation of the liquid into fractions, which leads to the unevenness of the process of its combustion. In addition, the presence of water significantly reduces the calorific value, which leads to abandon its energy use. Despite the fact that at $280{ }^{\circ} \mathrm{C}$ there is a general reduction of the mass of the organic part and, accordingly, the calorific value, the calorific value of the organic part of the liquid is increased. This suggests that with growth of temperature, the proportion of heavy hydrocarbon compounds that have a higher calorific value is raised (Fig. 5).

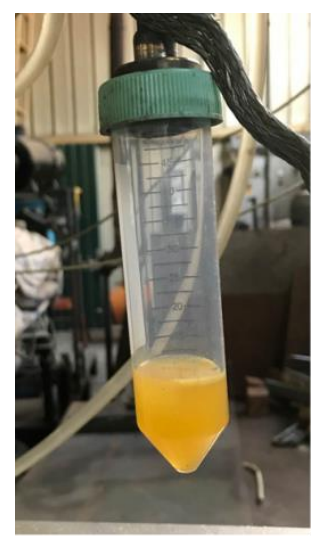

A

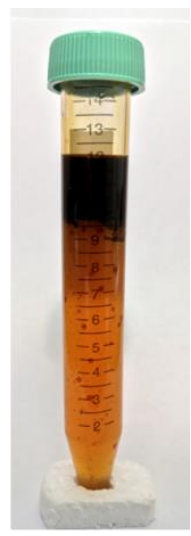

B
Fig. 5. Appearance of torrefaction liquid obtained at $260{ }^{\circ} \mathrm{C}$ (A) and $300{ }^{\circ} \mathrm{C}(\mathrm{B})$.

\subsection{Torrefaction non-condensable gases}

The change of the specific volume yield of noncondensable torrefaction gases is shown in Fig. 6. 


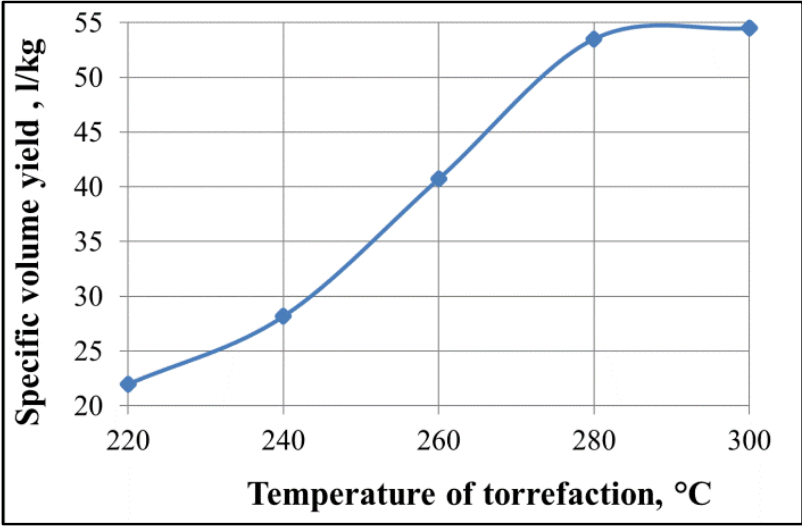

Fig. 6. Dependence of the specific volume yield of noncondensable torrefaction gases on the heating temperature of the raw materials.

As in the case of the liquid fraction, the amount of non-condensable gases increases with the growth of torrefaction temperature. But unlike a liquid, when the temperature reaches $280{ }^{\circ} \mathrm{C}$, gas yield is reduced. With increasing temperature, the specific volume yield of noncondensable torrefaction gases have raised from $22 \mathrm{l} / \mathrm{kg}$ at $220{ }^{\circ} \mathrm{C}$ to $54.5 \mathrm{l} / \mathrm{kg}$ at $300{ }^{\circ} \mathrm{C}$.

The results of measuring the chemical composition and determining the lower calorific value of noncondensable torrefaction gases are presented in Table 4.

Table 4. Characteristics of non-condensable torrefaction gases.

\begin{tabular}{|c|c|c|c|c|c|}
\hline & \multicolumn{5}{|c|}{ Temperature of torrefaction, ${ }^{\circ} \mathrm{C}$} \\
\hline & 220 & 240 & 260 & 280 & 300 \\
\hline \multicolumn{6}{|c|}{ Composition, vol. \% } \\
\hline $\mathrm{CO}_{2}$ & 88.8 & 85.9 & 83.0 & 82.5 & 79.5 \\
\hline $\mathrm{CO}$ & 8.7 & 11.5 & 14.4 & 14.9 & 17.8 \\
\hline $\mathrm{CH}_{4}$ & 0.4 & 0.6 & 1.0 & 1.1 & 1.4 \\
\hline NO & 0.1 & 0.1 & 0.1 & 0.1 & 0.2 \\
\hline $\mathrm{NO}_{2}$ & 0.9 & 0.8 & 0.6 & 0.6 & 0.5 \\
\hline $\mathrm{SO}_{2}$ & 0.6 & 0.5 & 0.4 & 0.4 & 0.3 \\
\hline $\mathrm{H}_{2} \mathrm{~S}$ & 0.6 & 0.5 & 0.4 & 0.4 & 0.4 \\
\hline Total & 100 & 100 & 100 & 100 & 100 \\
\hline \multicolumn{6}{|c|}{ Lower calorific value, $\mathrm{kJ} / \mathrm{m}^{3}$} \\
\hline$Q_{g}$ & 782 & 1248 & 1640 & 1722 & 2178 \\
\hline
\end{tabular}

The largest part of non-condensable gases is carbon dioxide $(79.5-88.8 \%)$. With growth of temperature, the proportions of carbon monoxide (from 8 to $18 \%$ ) and of methane (from 0.4 to $1.4 \%$ ) is increased. However, since the most of the gases in the gas mixture are energy useless $\left(\mathrm{CO}_{2}, \mathrm{NO}_{\mathrm{x}}, \mathrm{H}_{2} \mathrm{~S}, \mathrm{SO}_{2}\right)$, the calorific value of the mixture remains low. Given the small specific volume yield, it can be argued that non-condensable torrefaction gases are not of interest for energy using.

\section{Conclusions}

As a result of the experimental study, it was found that among all the products of torrefaction of chicken litter, solid residue has the highest energy potential. It has the significant mass yield and has the highest calorific value. The optimum regime of torrefaction of chicken litter is the temperature of $280{ }^{\circ} \mathrm{C}$ and the heating time of 40 minutes. At this condition the maximum improvement of the fuel characteristics of chicken litter is reached. The lower calorific value increases by $30 \%$, the limit of hygroscopicity decreases by 2.3 times. Despite the fact that at this temperature the bulk density is reduced by $25 \%$ compared with the feedstock, the energy yield of the torrefied product in the same volume is higher than for initial raw material.

The low mass yield combined with the high water content of the torrefaction liquid makes it uninteresting from the point of view of direct energy use. The low calorific value due to the high $\mathrm{CO} 2$-content and specific volume yield also make the non-condensable torrefaction gases unattractive from an energy point of view.

\section{Acknowledgment}

This work was carried out at the Joint Institute of High Temperatures of the Russian Academy of Sciences with financial support of the Russian Foundation for Basic Research (project number 19-08-00744).

\section{References}

1. P. Pradhana, S.M. Mahajanib, A. Arora Fuel Process. Technol., 181, 215-232(2018).

2. S. Gent, M. Twedt, C. Gerometta, E. Almberg Theoretical and Applied Aspects of Biomass Torrefaction: For Biofuels and Value-Added Products (2018).

3. Q. Maa, K.P. Paudelb, L. Cui. Appl. Energy, 228, 1220-1242 (2018)

4. I. Cem Kantarli, A. Kabadayi, S. Ucar,. J. Waste Manage. 56, 530-539 (2016).

5. V.N. Kozlov, A.A. Nimvitsky, Pyrogenetic technology of wood processing (Moscow; Leningrad: Goslesbumizdat, 1954).

6. B.J. He, Y. Zhang, T.L. Funk, G.L. Riskowski, Y. Yim. Trans ASAE, 46, 1827-1833. (2013).

7. P.C.A. Bergman, A.R. Boersma, R.W.H. Zwart, J.H.A. Kiel, Energy Research Centre of the Netherlands. ECN Report ECN-C-05-013 (2005).

8. G. Quiroga, L. Castrillón, Y. Fernández-Nava, E. Marañón, J. Waste Manage., 30, 880-884 (2010).

9. EH 14961-1:2010 Solid biofuels. Fuel specifications and classes, (Standartinform, 2012).

10. R. Isemin, D. Klimov, O. Larina, A. Mikhalev, V. Zaichenko, Chem. Eng. Trans., 67, 505-510 (2018).

11. EN 15103: 2009. Solid biofuels. Determination of bulk density. (Standartinform, 2015).

12. GOST 16483.32-77 Wood. Method for determination of ultimate higroscopicity. (Standartinform, 1999). 
13. A. F. Kuftov Fuel and fuel the burning devices of thermal units of common industrial appointment: manual. (Bauman Moscow State Technical University, 2006). 